\title{
USING RFID TECHNOLOGY AT OPERATING A DRONE SWARMS IN COMMUNICATION SYSTEM MODE
}

\author{
Serhii O. Kravchuk, Irina M. Kravchuk \\ Institute of Telecommunication Systems \\ Igor Sikorsky Kyiv Polytechnic Institute, Kyiv, Ukraine
}

Background. Currently, of great interest for developers of modern distributed electronic communications systems are communication architectures based on a swarm (a connected set of separate mobile devices-nodes) of drones (small unmanned aerial vehicles, UAVs). At the same time, RFID technology is increasingly being used with various security systems. The field of joint application of RFID and UAV technologies has now become very extensive, as demonstrated by many publications.

Objective. The aim of the paper is to present the possibility of using radio frequency identification technology when a swarm of drones operates in the communication system mode, that is, the use of RFID to form control and traffic channels of a distributed self-organizing drone system.

Methods. The structural and functional methods of constructing a wireless network based on a drone swarm are investigated.

Results. An analytical review of the literature on the combined use of RFID and UAVs is presented. High interest in this topic is shown. A scenario has been developed for a swarm of drones operating in a self-organizing communication system using RFID technology.

The procedure for exchange of control commands in a swarm using RFID is described. A feature of this procedure is the presence of drone authorization in it, which can be performed using inductive coupling, when all drones in the swarm have their own specific passive tags, which are triggered (emitted) only if a signal from the reader hits them.

The frequency ranges and transmission powers of RFID systems are presented, which can be used for the scenario presented in the paper.

Conclusions. The use of RFID, first of all, makes it possible to provide an increase in protection against external interception of control channels, a decrease in the likelihood of external interference, and a decrease in the energy consumption of the on-board battery. Further research may include numerical modeling of the operation of a swarm of drones in the mode of a self-organizing communication system using RFID technology.

Keywords: unmanned aerial vehicle; a swarm of drones; self-organizing system; protection against external interception of control channels; drone control network.

\section{INTRODUCTION}

Currently, of great interest for developers of modern distributed electronic communications systems are communication architectures based on a swarm (a connected set of separate mobile units-nodes) of drones (small unmanned aerial vehicles, UAVs) [1] - [12].

The development of electronic communications technologies in terms of personal-level wireless systems (short range up to tens of meters) allows the development and formation of new communication infrastructures. In particular, Radio Frequency Identification (RFID) technology has become widespread, which is a method for automatic identification of objects, where data stored in so-called transponders, or RFID tags, are read or written using radio signals. Any RFID-system comprises a reader (reader or interrogator) and a transponder (also known as RFID-tag).
By reading range, RFID systems can be divided into systems:

- close identification (reading is performed at a distance of up to $20 \mathrm{~cm}$ );

- identification of medium range (from $20 \mathrm{~cm}$ to 5 $\mathrm{m})$;

- long distance identification (from $5 \mathrm{~m}$ to $300 \mathrm{~m}$ ).

Currently, RFID is a generic term used to describe a system that transmits identification (in the form of a unique serial number) of an object or person over a wireless network using radio waves. It is grouped into a broad category of automatic identification technologies [13]. RFID is increasingly being used with biometric technology for security purposes. The field of application of RFID and UAV technologies has now become very extensive, which is demonstrated by many publications, the analysis of which is given in the next section. 
The main purpose of this work is to present the possibility of using radio frequency identification technology when a swarm of drones operates in a communication system mode, that is, the use of RFID to form control and traffic channels of a distributed selforganizing drone system.

\section{REVIEW OF PUBLICATIONS ON RFID AND UAV JOINT APPLICATION}

The combination of RFID technology and dronebased aerial platforms allows the creation of new wireless communication systems with certain unique properties. So, in [14] the paradigm of combining radio frequency identification RFID with unmanned aerial vehicle technology is presented, which gave rise to the so-called RFIDrone devices. This family of drones includes the READER-Drone, which is a UAV with an autonomous RFID reader that acts as a mobile environment scanner, and the TAGDrone based UAV, which is equipped only with an RFID sensor tag, which therefore becomes a mobile and automatically updated positioned sensor. Several electromagnetic models are being demonstrated to characterize RFIDrone communication in close proximity to a scattering surface. The results of some preliminary experiments in open space are presented, confirming the developed theoretical models. In [15], an integrated UAV-RFID platform based on an unmanned aerial vehicle and RFID devices is proposed. Such a platform uses deep learning algorithms to localize the position of an RFID tag within an acceptable range of accuracy.

In [16], a system is presented that consists of RFID tags located on a certain territory and a reader installed on an unmanned aerial vehicle. A methodology for testing such a system is presented and some of the achieved characteristics in a test scenario are analysed. The idea is to use the UAV to collect data from RFID sensors scattered throughout the area, simply by flying up to them and downloading the measured data.

The idea of winged tags for ubiquitous and dynamic monitoring of harsh environmental conditions and large interior spaces is described in [17]. Described and experimentally characterized here is the Tag-Drone concept consisting of an inexpensive nano-quadcopter and a miniature RFID tag with temperature measurement capability. The weight of the RFID sensor is comparable to the modest payload of a quadcopter and can be polled up to three meters away. Thus, a simple experimental procedure is described, involving a reproducible Tag-Drone guided flight, for evaluating time windows of visibility relative to a base station for in-flight communication under various operating conditions.

An RFID flight tracking and data collection system, which includes a server with a communication interface for sending and receiving data from an unmanned aerial vehicle, is presented in [18]. The server is also designed to receive a data packet including environmental sensor data and RFID tag ID from UAV, where the RFID tag ID and temperature sensor data in the ambient sensor data are generated by the ground device. The server is used to create a graphical user interface, including the presentation of data from environmental sensors.

In [19], the necessity of using unmanned aerial vehicles in the environment of the RFID radio frequency identification sensor network for the development of critical applications is emphasized. UAVs can act as data loggers and provide localization in such an integrated environment. This paper compares localization methods using UAVs. As a result of such comparisons, the need to establish localization using UAVs is foreseen, which requires rigorous mathematical models, approaches and experimental installations.

The combined use of UAVs and RFID devices is a new topic in environmental monitoring that combines the versatility of multi-copters with the capabilities of inexpensive wireless sensors [20]. Here are some performance metrics suitable for quantifying RFIDrone's ability to scan a surface equipped with radio sensors. Using simple propagation models, the optimal distance between the drone and the surface is mathematically calculated to maximize the EM footprint for a specific choice of system parameters such as sensor type and position, reader sensitivity, ground reflectivity, radiated power, and flight speed. Theoretical advances and some preliminary experiments show that omnidirectional antennas are preferable for the drone, so that a coverage area of $9 \ldots$ $12 \mathrm{~m}$ can be reached using modern readers and RFID sensors without batteries or with battery power, provided that the UAV flies at a distance of $3 \ldots 5 \mathrm{~m}$ from the controlled surface.

In [21], RFID technology has been widely studied as one of the methods for collecting location data. The purpose of this study was to overcome the limitations of existing approaches by proposing a localization method based on the integrated UAV-RFID platform.

Although unmanned aerial vehicles are usually deployed outdoors, there is growing interest in the use of UAVs for indoor use [22]. It is a very attractive and challenging task to accurately locate a UAV in an indoor environment where there is no global positioning system (GPS) service. This article introduces RFUAV, 
an advanced RFID UAV system that provides precise 6-DOF positioning for UAVs. With RFUAV, three or more ultra-high frequency (UHF) RFID tags are attached to the UAV and polled by a commercial RFID reader with multiple antennas. Based on the phase measurements of the responses of RFID tags, the RFID tracker RFUAV, using a Bayesian filter algorithm, tracked the position of the tags in the global coordinate system. The experimental results of measuring the UAV positions showed that position errors of $0.04 \mathrm{~m}$ and an orientation error of 2.5 degrees were achieved.

[23] discusses a wireless communication network (WPCN) system that uses several unmanned aerial vehicles. Ground users (GU) first collect energy from a mobile UAV with a wireless energy transfer WET, and then use this energy to transmit their information to a data gatherer (DG) UAV. The operation maximizes the minimum throughput for all GUs by jointly optimizing UAV trajectories and allocating WET UAV and GU resources. Due to the nonconvexity of the problem posed, an alternating optimization algorithm is proposed that uses sequential convex optimization methods to solve the problem; UAV trajectories and resource allocation are alternately optimized at each iteration. Numerical results show the effectiveness of the proposed algorithm under various scenarios.

A drone-based system is proposed for checking the presence of military personnel in the permitted area, which includes RFID radio frequency identification sensors and biosensors (Bio-sensors) [24]. It uses biosensors, namely Electric Potential Sensors (EPS), to check a person's heart rate and send data to the drone.

In [25], a communication system is studied using a fixed-wing UAV that collects information from a group of distributed ground terminals (GT). Taking into account the requirements for quality of service (QoS) (the throughput of each GT is above a given threshold) and GT scheduling, the UAV energy efficiency in bits / Joule is maximized by optimizing the UAV flight path. The article formulates a mixed integer nonconvex optimization problem. An efficient iterative algorithm is proposed that jointly optimizes GT planning and UAV trajectory.

An RFID based human-unmanned aerial vehicle interaction system is presented to provide an intuitive and easy-to-use method for UAV indoor navigation [26]. It is based on passive RFID technology, which allows you to accurately track the position of a handheld controller and then transmit that position information for UAV navigation.

[27] presents Relay Fly (RFly), a system that uses drones as repeaters for networks without batteries. RFly offers two key innovations. The system uses full duplex relaying for battery-free networks. The repeater can easily integrate with an already deployed RFID infrastructure, and retains the phase and time characteristics of the packets being forwarded. RFly also uses a new RF localization algorithm that can work through a mobile repeater. The results of the experiment showed that RFly can communicate with commercial RFID at a distance of more than $50 \mathrm{~m}$. In addition, the presented localization algorithm through a repeater has an average accuracy of $19 \mathrm{~cm}$.

In recent years, the Internet of Things (IoT) has experienced unprecedented development and has become widely used in logistics, automated scheduling and other fields. In various IoT applications, RFID is in the spotlight. Like other wireless devices, RFID tags face an acute collision problem that affects the efficiency of the IoT system. In [28], a new collision avoidance algorithm for IoT is proposed, which is called the UAV-based multiple tags anti-collision protocol (UMTAP). UMTAP protocol uses a UAVbased reader to identify multi-frequency tags, which can effectively solve the problem of tag collision in dense IoT environments. Simulation results show that UMTAP has better performance than existing algorithms in terms of system efficiency and identification time.

Advances in drone technology offer unprecedented opportunities for the development of a wide range of large-scale IoT applications [29]. However, UAV platforms still face important limitations, mainly related to autonomy and weight, which affect their remote sensing capabilities in collecting and processing the data required to develop autonomous and reliable realtime obstacle avoidance and detection systems. [29] provides an overview of the latest developments in the field of unmanned aerial systems (Deep Learning) DL and basic DL techniques. In addition, DL-UAV communication architectures are studied and their most common equipment analysed. It identifies the most pressing open issues for current DL-UAV solutions, allowing future researchers to define a roadmap for affordable next-generation DL-UAV IoT autonomous solutions.

In [30], a system based on an UAV is presented, aimed at automating the tasks of inventorying and tracking industrial facilities attached to RFID tags. To counter current shortcomings, such a system is being developed based on a universal, modular and scalable architecture aimed at enhancing cybersecurity and decentralization while encouraging external auditing and big data analysis. Such a system uses blockchain and a distributed ledger to store certain inventory data 
collected by the UAV, validate it, ensure its reliability, and provide access to interested parties.

One obstacle to widespread adoption of passive RFID systems is the limited read distance or relatively high error rate due to radio interference in passive backscatter RFID systems. The most important performance characteristic of a tag is the read distance at which the RFID reader can detect the signal reflected from the tag. The reading distance in passive backscatter RFID systems depends on many factors. [31] provides an overview of RFID systems with passive backscattering and transmission models of these systems.

Tremendous advances in electronic technology and RFID technology make it possible to implement additional functions in transponders. It should be noted that passive or semi-passive transponders receive energy from the electromagnetic field generated by the $\mathrm{read} /$ write device and its antenna. This power supply is used for the radio communication process, and the excess energy can be used to power additional electronic circuits. However, the challenge is to determine the effect of the additional load power on the correct operation of the RFID system and the size of the polling area. The possibility of supplying additional electronic units used in passive transponders is discussed in detail in [32].

The results of the analysis of the presented works demonstrate the absence of publications on the use of RFID for the formation of control channels and traffic of a distributed self-organizing system of drones, which is the purpose of this work and confirms its relevance.

\section{SCENARIO OF A DRONE SWARMS IN THE MODE OF A SELF-ORGANIZING COMMUNICATION SYSTEM}

The work of a swarm of drones, which has the property of self-organization (robotic system), differs significantly from the work of the usual link of a number of drones performing a connected function. The differences are related to the following: a selforganizing swarm of drones can operate independently without being connected to ground or air control centers or traffic (transmitted payload). Moreover, its functioning in an independent flight requires high secrecy and noise immunity, as well as minimizing energy consumption. These requirements can be met by using RFID technology.

RFID application allows us to provide:

- increasing protection against external interception of control channels;

- reducing the likelihood of setting external interference;
- reducing the energy consumption of the onboard battery;

- local government: interruption and initialization of the mission; drone activation; drone interaction;

- new swarm modes: tag monitoring mode (biosensors search for living people); control mode via RFID channels; manual control mode for a swarm of drones;

- joint work of RFID and wireless personal-level systems;

- low cost.

Drones can be authorized using inductive coupling, when all drones in a swarm have their own specific passive tags, which are triggered (emit) only if a signal from a reader hits them. The latter can be located both on all drones, and only on one leading drone of the swarm.

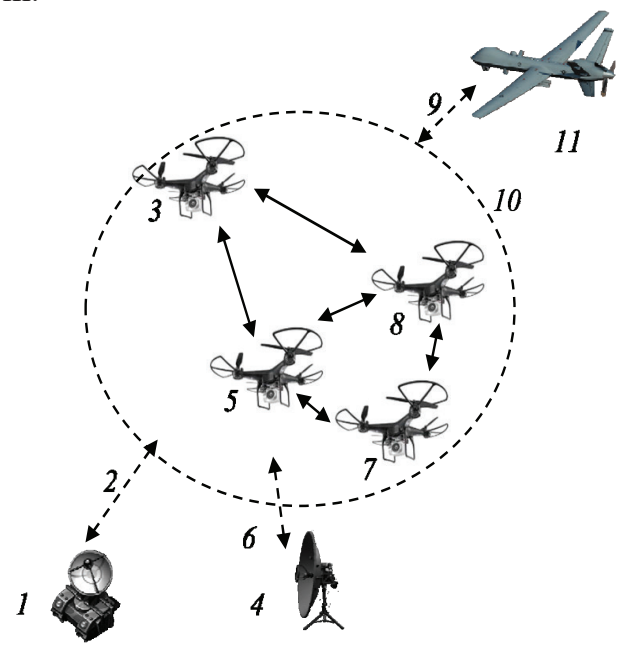

Fig. 1. Scenarios of a swarm of drones in the mode of a selforganizing communication system: 1 - ground point of jamming or interception; 2, 6, 9 - communication lines with external sources of useful or "harmful" signals; 3, 5, 7, 8-drones; 4 - ground control point; 10 - swarm boundaries and scope of possible RFID application; 11 - flying machine (manned aircraft)

Consider a scenario for using RFID for a drone swarm. Initially, a swarm of drones is deployed in a certain location in radio silence mode (external control and traffic channels are disabled) (drones 3, 7, 8 in Fig. 1). Then the activator in the form of an unmanned drone (5 in Fig. 1) or a manned aircraft (11 in Fig. 1) flies into the swarm hovering zone (10 in Fig. 1), turns on its RFID reader and activates the passive RFID tags of the swarm drones. At the same time, short-range radio channels are formed between them, through which control channels are switched on to initialize the swarm to perform the task assigned to it and transfer (exchange) information accumulated in the swarm (if any). Useful information can be transmitted both to the activator and to the ground data collection point (4 in Fig. 1). With all these procedures, the swarm drones do 
not work to receive radio signals from external remote sources ( 1 or 11 in Fig. 1), especially those that can interfere with or conduct radio interception by controlling the swarm.

Later, after activation, the swarm drones can use RFID channels to communicate with each other, keeping radio silence on all other communication channels that are usually present on board, for example, Wi-Fi.

The presence on the drones of an independent RFID channel with passive tags allows them to synchronize the control data for authorization and eliminate attempts to withdraw / capture any of the drones in the swarm, which, if necessary, conducted an external remote radio session.

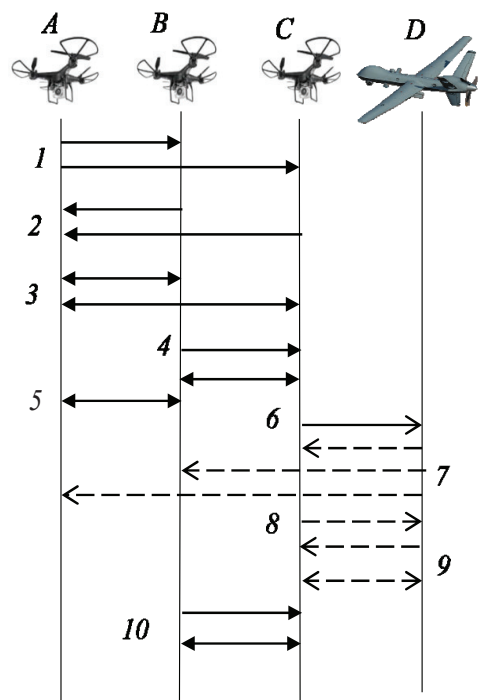

Fig. 2. Procedures for exchanging control commands in a swarm using RFID

An example of the procedures for exchanging control commands in the presented scenario of a swarm of drones using RFID is shown in Fig. 2. Three drones ( $A$, $B, C)$ are considered here, the first $(A)$ of which is a swarm activator, and an external flying radio intercept point $D$. The sequence of steps of the procedure is as follows:

1) drone $A$ turns on its reader and activates passive tags on drones $B$ and $C$;

2) activated drones establish return channels for response and confirmation to establish a connection;

3) radio channels are established according to RFID technology between drone $A$ and drones $B, C$;

4) drone $B$ turns on its RFID reader and establishes a communication channel with drone $C$;

5) Drone $A$ remains connected to the drones and thus joins the swarm through RFID-supported control channels. At this step, a swarm of interacting drones is formed, which is ready to perform the task assigned to it;

6) The beginning of the swarm's task. To do this, one of $C$ 's drones needs to get in touch with the ground terminal. At the same time, accordingly, on board this drone, high-frequency equipment will be turned on, which supports communication over long distances and which can serve to intercept the signal of the drone $C$, the radio interception point $D$.

7) interception point $D$ begins to attempt to intercept (or jam) in the direction of the signal received from the drone. Many of the swarm's drones may be exposed to radiation, but they remain radio silent and therefore not subject to interceptor processing;

8) only drone $C$ can answer and get under the "processing" of the interceptor signal;

Table 1 - Ranges of frequencies and transmission power of RFID

\begin{tabular}{|c|c|c|}
\hline $\begin{array}{l}\text { Frequency } \\
\text { range }\end{array}$ & Description & $\begin{array}{l}\text { Acceptable } \\
\text { levels }\end{array}$ \\
\hline$<135 \mathrm{kHz}$ & LF, inductive coupling & $72 \mathrm{~dB} \cdot \mu \mathrm{A} / \mathrm{m}$ \\
\hline $\begin{array}{l}6.765-6.795 \\
\mathrm{MHz}\end{array}$ & $\begin{array}{l}\text { MF (ISM), inductive } \\
\text { coupling }\end{array}$ & $42 \mathrm{~dB} \cdot \mu \mathrm{A} / \mathrm{m}$ \\
\hline $\begin{array}{l}7.400-8.800 \\
\mathrm{MHz}\end{array}$ & MF used only in EAS & $9 \mathrm{~dB} \cdot \mu \mathrm{A} / \mathrm{m}$ \\
\hline $\begin{array}{l}13.553- \\
13.567 \mathrm{MHz}\end{array}$ & $\begin{array}{l}\text { HF (13.56 MHz, ISM), } \\
\text { inductive coupling, } \\
\text { widespread in systems } \\
\text { with contactless smart } \\
\text { cards (ISO 14443, } \\
\text { MIFARE, LEGIC, ...), } \\
\text { smart tags (ISO 15693, } \\
\text { Tag-It, I-Code, ...), as } \\
\text { well as in the field of } \\
\text { facility management } \\
\text { (ISO 18000-3) }\end{array}$ & $42 \mathrm{~dB} \cdot \mu \mathrm{A} / \mathrm{m}$ \\
\hline $\begin{array}{l}26.957- \\
27.283 \mathrm{MHz}\end{array}$ & $\begin{array}{l}\text { RF (ISM), inductive } \\
\text { coupling, for special } \\
\text { applications only }\end{array}$ & $42 \mathrm{~dB} \cdot \mu \mathrm{A} / \mathrm{m}$ \\
\hline $433 \mathrm{MHz}$ & $\begin{array}{l}\text { UHF (ISM), scatter } \\
\text { feedback, rarely used in } \\
\text { RFID }\end{array}$ & $10-100 \mathrm{~mW}$ \\
\hline $\begin{array}{l}868-870 \\
\mathrm{MHz}\end{array}$ & $\begin{array}{l}\text { UHF (SRD), scatter } \\
\text { feedback, new } \\
\text { frequency, systems in } \\
\text { development }\end{array}$ & $\begin{array}{l}500 \mathrm{~mW} \text {, only in } \\
\text { Europe }\end{array}$ \\
\hline $\begin{array}{l}902-928 \\
\mathrm{MHz}\end{array}$ & $\begin{array}{l}\text { UHF (SRD), scatter } \\
\text { feedback, used in } \\
\text { multiple systems }\end{array}$ & $\begin{array}{l}4 \mathrm{~W} \text { - wide } \\
\text { range, only in } \\
\text { USA / Canada } \\
\end{array}$ \\
\hline $\begin{array}{l}2,400-2,483 \\
\mathrm{GHz}\end{array}$ & $\begin{array}{l}\text { Microwave (ISM), } \\
\text { scatter feedback, used in } \\
\text { several systems (vehicle } \\
\text { identification - } 2.446- \\
2.454 \mathrm{GHz} \text { ) }\end{array}$ & $\begin{array}{l}\mathrm{W}-\text { wide } \\
\text { range, only in } \\
\text { USA / Canada; } \\
500 \mathrm{~mW} \text {, only in } \\
\text { Europe }\end{array}$ \\
\hline $\begin{array}{l}5.725-5.875 \\
\mathrm{GHz}\end{array}$ & $\begin{array}{l}\text { UHF (ISM), scatter } \\
\text { feedback, rarely used in } \\
\text { RFID }\end{array}$ & $\begin{array}{l}4 \text { W - USA } \\
\text { Canada; } 500 \\
\text { mW - Europe }\end{array}$ \\
\hline
\end{tabular}


SRD (short-range device), EAS (electronic article Surveillance), ISM (industrial, scientific and medical), ISO (International Organization for Standardization).

9) interceptor $D$ begins attempts to control drone $C$ or violate its flight mission (introducing various errors). At the same time, through the independent control channels supported inside the swarm, RFID will be transmitted from the drone $C$ to the swarm an error or alarm signal;

10) the swarm's reaction to an alarm or error will be the transmission of the currently updated control information to the drone $C$ and the disconnection of external remote communication channels, thereby stopping the maintenance of the communication channel with the interceptor $D$.

\section{FREQUENCY BANDS FOR SYSTEMS USING RFID}

An RFID reader emits electromagnetic waves, which is why RFID systems are classified as radio systems. At the same time, the functioning of other services operating in the radio range, under no circumstances should be disrupted or weakened by the work of RFID systems. It is especially important to have assurances that RFID systems do not interfere with radio and television, mobile communications, and military and aviation services.

The need to accommodate other services significantly limits the range of operating frequencies available to RFID systems. For this reason, only those frequencies are usually available for use that have been specifically reserved for use in the fields of science, industry or medicine, as well as frequencies for shortrange devices.

Most RFID systems today operate in three bands: low frequencies (LF), high frequencies (HF), and ultrahigh frequencies (UHF), as shown in table. 1.

\section{v. Conclusion}

An analytical review of the literature on the combined application of RFID and UAV is presented. High interest in this topic is shown. The results of the analysis of the reviewed publications demonstrate the lack of work on the use of RFID for the formation of control channels and traffic of a distributed selforganizing drone system.

A scenario has been developed for a swarm of drones operating in a self-organizing communication system using RFID technology. The use of RFID, first of all, makes it possible to provide an increase in protection against external interception of control channels, a decrease in the likelihood of external interference, and a decrease in the energy consumption of the on-board battery.

The procedure for exchange of control commands in a swarm using RFID is described. A feature of this procedure is the presence of drone authorization in it, which can be performed using inductive coupling, when all drones in the swarm have their own specific passive tags, which are triggered (emitted) only if a signal from the reader hits them.

The frequency ranges and transmission powers of RFID systems are presented, which can be used for the scenario presented in the work.

Further research may include numerical modeling of the operation of a swarm of drones in the mode of a self-organizing communication system using RFID technology.

\section{REFERENCES}

1. Boyle M.J., The Drone Age How Drone Technology Will Change War and Peace: Oxford University Press, 2020, 376 p., ISBN: 9780197501788 (online)

2. Autonomous Flying Robots: Unmanned Aerial Vehicles and Micro Aerial Vehicles, K. Nonami, F. Kendoul, S. Suzuki, W. Wang, D. Nakazawa, Springer Japan, 2010, 329 p. (eBook ISBN 978-4-431-53856-1).

3. Ilchenko M.Y., Kravchuk S.O., Telecommunication systems: Kyiv, Naukova dumka, 2017, 736 p. (ISBN: 978-966-00-1566-1), (in Ukraine).

4. Ilchenko M., Kravchuk S., Telecommunication systems based on highaltitude aerial platforms: Naukova Dumka, 580 p., 2008 (ISBN 978-96600-0715-4) (ru)

5. Ilchenko M., Kravchuk S., Kaydenko M., "Combined Over-theHorizon Communication Systems", in: Advances in Information and Communication Technologies. Processing and Control in Information and Communication Systems. UKRMICO 2018. Lecture Notes in Electrical Engineering, vol 560. Springer, Cham, 2019 - pp. 121-145. DOI: 10.1007/978-3-030-16770-7 (https://doi.org/10.1007/978-3-030-16770-7_6)

6. Kravchuk S.O., Aphanasieva L.O., "Resources distribution for the telecommunication systems based on aero-platform", Dig. of the 12th International Scientific conf. "Modern Challenges in Telecommunications", April 16-20, 2018, Kyiv, Ukraine. - K.: Himjest, 2018. - pp. 201-204.

7. Kravchuk S.O., Aphanasieva L.O., Kravchuk I.M., "Hierarchical control system and telemetry for intelligent unmanned aerial vehicles", Dig. of the 12th International Scientific conf. "Modern Challenges in Telecommunications", April 16-20, 2018, Kyiv, Ukraine. - K.: Himjest, 2018. - pp. 187-190.

8. Ilchenko M.Y., Kaydenko M.M., Kravchuk S.O., "Structuralfunctional principles of management and communication systems for border and landscape equipment of the telecommunication network on the basic of aeroplatform", Dig. of the 12th International Scientific conf. "Modern Challenges in Telecommunications", April 16-20, 2018, Kyiv, Ukraine. K.: Himjest, 2018. - pp. 26-29.

9. Kaidenko M., Kravchuk S., "Creation of communication system for unmanned aerial vehicles using SDR and SOC technologies", IEEE 2019 International Conference on Information and Telecommunication Technologies and Radio Electronics (UkrMiCo), Sept 9-13, 2019, pp. 1-4 (IEEE Xplore Digital Library, DOI: 10.1109/UkrMiCo47782.2019.9165422)

10. Kaidenko M., Kravchuk S., "Autonomous Unmanned Aerial Vehicles Communications on the Base of Software-Defined Radio", in: Ilchenko M., Uryvsky L., Globa L. (eds) Advances in Information and Communication Technology and Systems. MCT 2019. Lecture Notes in Networks and Systems, vol 152. Springer, Cham. pp. 289-302 (2019) https://doi.org/10.1007/978-3-030-58359-0_16

11. Kravchuk S., Afanasieva L., "Formation of a wireless communication system based on a swarm of unmanned aerial vehicles", Information and 
Telecommunication Sciences, No 1, pp. 11-18 (2019) DOI: https://doi.org/10.20535/2411-2976.12019.11-18

12. Kravchuk S., Kaidenko M., Afanasieva L., I. Kravchuk, "Testing of the drone swarms as a communication relay system", Information and Telecommunication Sciences, Vol. 11, Number 1, pp. 92-101 (2020) (DOI: https://doi.org/10.20535/2411-2976.12020.92-101).

13. Kaur M., Sandhu M., Mohan N. and Sandhu P.S., RFID Technology Principles, Advantages, Limitations \& Its Applications, International Journal of Computer and Electrical Engineering, Vol.3, No.1, pp. 1793-8163 (2011) (DOI: 10.7763/IJCEE.2011.V3.306).

14. Longhi M., Casati G., Latini D., Carbone F., Del Frate F. and Marrocco G., «RFIDrone: Preliminary Experiments and Electromagnetic Models», 2016 URSI International Symposium on Electromagnetic Theory (EMTS), Aug. 14-18, 2016, Espoo, Finland (DOI: 10.1109/URSIEMTS.2016.7571423)

15. Wona D., Chib S., and Park M.-W., UAV-RFID Integration for Construction Resource Localization, KSCE Journal of Civil Engineering, pp.1-13 (2020) (DOI 10.1007/s12205-020-2074-y)

16. Greco G., Lucianaz C., Bertoldo S., Allegretti M., A solution for monitoring operations in harsh environment: a RFID reader for small UAV, In: 2015 International Conference on Electromagnetics in Advanced Applications (ICEAA), Torino (ITA), September 7-11, 2015. pp. 859-862 (DOI:10.1109/ICEAA.2015.7297235)

17. LONGHI M. and MARROCCO G., Flying Sensors: merging NanoUAV with Radiofrequency Identification, 2017 IEEE International Conference on RFID Technology \& Application (RFID-TA), Sept. 20-22, 2017, Warsaw, Poland (DOI: 10.1109/RFID-TA.2017.8098875)

18. Patent Application Publication (US) "Aerial Radio - Frequency Identification (RFID) Tracking and Data Collection System", T.D. Howard, C.S. Pataky, Pub. No.: US 2019 / 0122455 A1, Int . CI . G07C 5/08, G05D $1 / 02$

19. Jasrotia D. S., Nene M. J., Localisation using UAV in RFID and Sensor Network Environment: Needs and Challenges, 2019 International Conference on Computing, Communication, and Intelligent Systems (ICCCIS), Oct. 18-19, 2019, Greater Noida, India, pp. 274-279 (2019) (DOI: 10.1109/ICCCIS48478.2019.8974536).

20. Casati G., Longhi M., Latini D., Carbone F., Amendola S., Del Frate F., Schiavon G., and Marrocco G., The Interrogation Footprint of RFIDUAV: Electromagnetic Modeling and Experimentations, IEEE JOURNAL OF RADIO FREQUENCY IDENTIFICATION, VOL. 1, NO. 2, pp. 155162 (2017) (DOI: 10.1109/JRFID.2017.2765619).

21. Won D., Park M.-W., Chi S., Construction Resource Localization Based on UAV-RFID Platform Using Machine Learning Algorithm, 2018 IEEE International Conference on Industrial Engineering and Engineering Management (IEEM), Dec. 16-19, 2018, Bangkok, Thailand, (DOI: 10.1109/IEEM.2018.8607668).

22. Zhang J., Wang X., Yu Z., Lyu Y., Mao S., CG Periaswamy S., Patton J., Wang X., "Robust RFID Based 6-DoF Localization for Unmanned Aerial
Vehicles", IEEE Access, Vol. 7, pp. 77348 - 77361 (2019) (DOI: 10.1109/ACCESS.2019.2922211).

23. Wu F., Yang D., Xiao L. and Cuthbert L., "Minimum-Throughput Maximization for Multi-UAV-Enabled Wireless-Powered Communication Networks", Sensors, 19, 1491p. (2019) (doi:10.3390/s19071491).

24. Dhar A., Saha M., Chaudhuri S., Gupta A., "Drone Embedded RFID and EPS Sensor based Military Survelliance", Int. J. Adv. Sci. Eng. Vol.6, No.S1, pp. 51-54 (2019) (https://doi.org/10.29294/IJASE.6.S1.2019.51-54).

25. Xu Y., Xiao L., Yang D., Cuthbert L., and Wang Y., Energy-Efficient UAV Communication with Multiple GTs Based on Trajectory Optimization, Hindawi Mobile Information Systems, Vol. 2018, Article ID 5629573, 10p. (2018) (https://doi.org/10.1155/2018/5629573)

26. RFHUI: an RFID based human-unmanned aerial vehicle interaction system in an indoor environment, J. Zhang, Z. Yu, X. Wang, Y. Lyu, S. Mao, S. Periaswamy, J. Patton, X. Wang, Digital Communications and Networks, 6, pp. 14-22 (2020) (https://doi.org/10.1016/j.dcan.2019.05.001).

27. Ma Y., Selby N., and Adib F., Drone relays for battery free networks, in Proceedings of the Conference of the ACM Special Interest Group on Data Communication. SIGCOMM'17, August 21-25, 2017, Los Angeles, CA, USA pp. 335-347 (https://doi.org/10.1145/3098822.3098847)

28. He Y., Zhang R., Jiang Y., Li B., Wang D., An Anti-Collision Protocol Based on UAV for Internet of Things, 2019 11th International Conference on Wireless Communications and Signal Processing (WCSP) Oct. 23-25, 2019 Xi'an, China (DOI: 10.1109/WCSP.2019.8927978)

29. Fraga-Lamas P., Ramos L., Mondéjar-Guerra V.and FernándezCaramés T. M., "A Review on IoT Deep Learning UAV Systems for Autonomous Obstacle Detection and Collision Avoidance", Remote Sensing, vol. 11, issue 18, 2144p. (2019) (DOI: 10.3390/rs11182144).

30. Fernández-Caramés T. M., Blanco-Novoa O., Froiz-Míguez I. and Fraga-Lamas P., "Towards an Autonomous Industry 4.0 Warehouse: A UAV and Blockchain-Based System for Inventory and Traceability Applications in Big Data-Driven Supply Chain Management", Sensors, 19 (10), 2394p. (2019) (https://doi.org/10.3390/s19102394)

31. Gao Y., Zhang Z., Lu H., Wang H., "Analysis and Calculation of Read Distance in Passive Backscatter RFID Systems", LISS 2012: Proceedings of 2nd International Conference on Logistics, Informatics and Service Science, Springer-Verlag Berlin Heidelberg 2013 (DOI 10.1007/978-3-642-32054-5_126).

32. Jankowski-Mihulowicz P., Kalita W., Skoczylas M. and Weglarski M., Modelling and Design of HF RFID Passive Transponders with Additional Energy Harvester, International Journal of Antennas and Propagation (Hindawi Publishing Corporation), Vol. 2013, Article ID 242840, 10p. (http://dx.doi.org/10.1155/2013/242840).

33. Laikov Y., Fatkullin A., RFID readers of ISO / IEC 15693 standard, Wireless technologies, no. 2, pp. 16-19 (2006) (https://wirelesse.ru/rfid/rfid/)

\section{Кравчук С.А., Кравчук I.M. \\ Використання технології радіочастотної ідентифікації при роботі рою дронів в режимі системи зв'язку}

Проблематика. В даний час великий інтерес для розробників сучасних розподілених систем електронних комунікацій представляють архітектури комунікацій на основі рою (пов'язаного безлічі окремих рухомих пристроїввузлів) дронів (малих безпілотних літальних апаратів, БПЛА). У той же час технологія RFID все частіше використовується 3 різними системами для забезпечення безпеки. Область спільного застосування RFID i БПЛА технологій стала в даний час дуже великої, що демонструють безліч публікацій.

Мета. Метою даної роботи є представлення можливості використання технології радіочастотної ідентифікації при роботі рою дронів в режимі системи зв'язку, тобто, використання RFID для формування каналів управління і трафіку розподіленої системи дронів, що самоорганізовується.

Методи. Досліджуються структурно-функціональні методи побудови безпроводової мережі на основі рою дронів.

Результати. Представлений аналітичний огляд літератури зі спільного застосування RFID i БПЛА. Показаний високий інтерес до даної теми. Розроблено сценарій роботи рою дронів в режимі самоорганізації зв'язкової системи при залученні технології RFID.

Описана процедура обміну керуючими командами в рої при використанні RFID. Особливістю даної процедури є наявність в ній авторизації дронів, яка може здійснюватися за допомогою індуктивного зв'язку, коли все дрони в рої 
мають свої специфічні пасивні мітки, які спрацьовують (випромінюють) тільки в разі потрапляння на них сигналу від зчитувача.

Представлені діапазони частот і потужностей передачі RFID-систем, які можуть бути застосовані для представленого в роботі сценарію.

Висновки. Застосування RFID, перш за все, дозволяє забезпечити підвищення захисту від зовнішніх перехоплень каналів управління, зниження ймовірності постановки зовнішніх перешкод, зменшення витрат енергії бортовий батареї. Подальшими дослідженнями можуть бути опрацювання по чисельному моделюванню роботи рою дронів в режимі самоорганізації зв'язкової системи при залученні технології RFID.

Ключові слова: безпілотний літаючий апарат; рій дронів; самоорганізована система; захист від зовнішніх перехоплень каналів управління; мережу управління дронами.

\section{Кравчук С.А., Кравчук И.М.}

Использование технологии радиочастотной идентификации при работе роя дронов в режиме системы связи

Проблематика. В настоящее время большой интерес для разработчиков современных распределенных систем электронных коммуникаций представляют архитектуры коммуникаций на основе роя (связанного множества отдельных подвижных устройств-узлов) дронов (малых беспилотных летающих аппаратов, БПЛА). В тоже время технология RFID все чаще используется с различными системами для обеспечения безопасности. Область совместного применения RFID и БПЛА технологий стала в настоящее время очень обширной, что демонстрируют множество публикаций.

Цель. Целью данной работы является представление возможности использования технологии радиочастотной идентификации при работе роя дронов в режиме системы связи, то есть, использование RFID для формирования каналов управления и трафика распределенной самоорганизующейся системы дронов.

Методы. Исследуются структурно-функциональные методы построения беспроводной сети на основе роя дронов.

Результаты. Представлен аналитический обзор литературы по совместному применению RFID и БПЛА. Показан высокий интерес к данной теме. Разработан сценарий работы роя дронов в режиме самоорганизующейся связной системы при задействовании технологии RFID.

Описана процедура обмена управляющими командами в рое при использовании RFID. Особенностью данной процедуры является наличие в ней авторизации дронов, которая может производиться при помощи индуктивной связи, когда все дроны в рое имеют свои специфические пассивные метки, которые срабатывают (излучают) только в случае попадания на них сигнала от считывателя.

Представлены диапазоны частот и мощностей передачи RFID-систем, которые могут быть применены для представленного в работе сценария.

Выводы. Применение RFID, прежде всего, позволяет обеспечить повышение защиты от внешних перехватов каналов управления, снижение вероятности постановки внешних помех, уменьшение расхода энергии бортовой батареи. Дальнейшими исследованиями могут быть проработки по численному моделированию работы роя дронов в режиме самоорганизующейся связной системы при задействовании технологии RFID.

Ключевые слова: беспилотный летающий аппарат; рой дронов; самоорганизующаяся система; защита от внешних перехватов каналов управления; сеть управления дронами. 